\title{
The effect of ecological factors on the mating system of a South American shrub species (Helicteres brevispira)
}

\author{
EDIVANI V. FRANCESCHINELLI* $† \&$ KAMALJIT S. BAWA $\ddagger$ \\ $\dagger$ Depto. de Botânica - ICB, Universidade Federal de Minas Gerais, Belo Horizonte, MG 31.270-110, Brazil and \\ $\ddagger$ Department of Biology, University of Massachusetts Boston, 100 Morrissey Blvd, Boston, MA 02125, U.S.A.
}

\begin{abstract}
Mating systems are influenced by several ecological factors, including plant density, number of flowers per plant, and pollinator movements. In this study, we investigated the simultaneous effects of these three factors on the mating system of a self-compatible Brazilian shrub species: Helicteres brevispira St. Hil. Outcrossing rate is directly correlated with plant density. Changes in the number of flowers per plant affect outcrossing rate through their effect on the density of flowers. Variation in foraging behaviour of hummingbird pollinators is a consequence of the interaction between plant density and number of flowers per plant. Territorialist pollinators are common in high density areas but visit few flowers on each plant, thereby promoting outcrossing. In areas of low plant density, trapliners and rare territorialists visit several flowers per plant, thus increasing selfing. Our results indicate that outcrossing rate is a dynamic parameter, with the extent of variation depending on a number of ecological factors. In successional species such as those in the genus Helicteres, demographic changes may be accompanied by alterations in mating system parameters, with concomitant effects on the genetic structure of populations.
\end{abstract}

Keywords: flower density, Helicteres, mating system, outcrossing rate, plant density, pollinator behaviour.

\section{Introduction}

Mating systems in plants can be influenced by several ecological factors. Wright (1946) demonstrated theoretically that inbreeding is inversely correlated with plant density and gene dispersal, if mating within neighbourhoods is random. As density increases, the effective number of reproducing individuals inside the neighbourhood areas also increases, as does the outcrossing rate. This is particularly true in plant species pollinated by animals, because pollinators tend to fly to the closest neighbour and most of the pollen is exchanged among neighbouring plants (Levin, 1986; Parra et al., 1993; Boshier et al., 1995; Stacy et al., 1996).

Several authors have suggested that high concentration of rewards in space may enhance pollinator activity between plants and thus pollen flow (e.g. Ausgspurger, 1980; Wyatt, 1980; Gerber, 1985). Others have suggested that this concentration may restrict pollinator movement and gene flow between plants and within populations (e.g. Linhart, 1973; Feinsinger, 1978; Schmitt, 1983; Stacy et al., 1996). Species with different spatial

*Correspondence. E-mail: edivani@mono.icb.ufmg.br patterns of floral rewards can also attract guilds of pollinators with distinct foraging strategies. For example, Linhart (1973) and Feinsinger (1978) found that species that produce few flowers per plant attract trapliner hummingbirds (which visit sequentially the same plants over a wide geographical area), whereas species that produce many flowers per plant are pollinated by territorial hummingbirds (which visit and defend flowering plants that are within their feeding territories). These authors have suggested that traplining and foraging over long distances should promote outcrossing, but that territorial foraging should result in inbreeding (see also Baker, 1973; Murawski, 1987, 1995). However, most studies that compare plant density and outcrossing rate support Wright's (1946) conclusion that there should be a positive correlation between these two parameters (Farris \& Mitton, 1984; Burdon et al., 1988; Wolff et al., 1988; Murawski et al., 1990, 1994; Murawski \& Hamrick, 1991, 1992a,b; van Treuren et al., 1993). Some authors have also suggested that plant size is an important factor in the relationship between outcrossing rate and plant density (Burdon et al., 1988; Wolff et al., 1988). Large shrubs and herbs 
produce more flowers in low than in high-density situations. The pollinators may thus be induced to visit a higher number of flowers per plant in populations that are less dense thereby increasing the probability of selfing (Crawford, 1984).

Although the effects of density and pollinator behaviour on mating systems have been examined before (Barret et al., 1994; Karron et al., 1995), no study has simultaneously considered the effects of plant density, flower number and pollinator behaviour on outcrossing rate. Helicteres brevispira St. Hil. is a very suitable species for this kind of study, because it is pollinated by territorial or traplining hummingbirds, depending apparently on the plant density and number of flowers per plant (Franceschinelli, 1989). Specifically, we address the following three questions. (i) What is the effect of plant density on the rate of outcrossing? (ii) How does the flower number per plant influence outcrossing? (iii) What is the effect of traplining and territorial foraging behaviour on the mating system?

\section{Materials and methods}

\section{Study site and species}

The fieldwork was conducted at the Mogi Guaçú Ecological Reserve $\left(22^{\circ} 18^{\prime} \mathrm{S}, 47^{\circ} 13^{\prime} \mathrm{W}\right)$, in São Paulo State, Brazil. This reserve comprises 980 ha of riparian semideciduous forest and savanna vegetation.

Helicteres brevispira is a shrub or small tree, up to $7 \mathrm{~m}$ tall. It is a common species in the transition from the semideciduous forest to savanna in central and southeastern Brazil. The plants have a clustered distribution in open areas and are linear or random on the forest edge. Franceschinelli (1989) showed that flowering among plants is synchronous, occurs after the first rains of the spring (in the first or second week of September), and lasts only one month. A few plants may have their flowering peak at a different time from the rest of the population. The number of flowers varies with the size of the plant. Large plants may bear 80-300 flowers a day and small ones, one to 30 . Most plants are of medium size (2-3 $\mathrm{m}$ tall) and produce $30-80$ flowers a day. The fruits are small capsules (3-4 cm length) with 20-60 seeds. At the study site this species is pollinated by the hummingbirds Chlorostilbon aureoventris and Amazilia lactea (Franceschinelli, 1989).

Helicteres brevispira is self-compatible (Franceschinelli, 1989), which indicates that this species may have a mixed-mating system; this is the main assumption of the method used here for calculating the outcrossing rate. Other assumptions of Ritland's mixed-mating model (Ritland \& Jain, 1981; Ritland, 1990) are: (i) all maternal genotypes outcross at the same rate to a homogeneous pollen pool; (ii) alleles at different loci segregate independently; (iii) each locus is at HardyWeinberg equilibrium; and (iv) the genetic markers are not affected by selection or mutation between pollination and the time of progeny census.

\section{Effect of plant density on outcrossing rate}

A population of $H$. brevispira (with 325 flowering plants) was mapped. Areas with different plant densities were distinguished. For analysis of outcrossing rates and their ecological correlates, two high- and two lowdensity areas were sampled (Fig. 1).

Leaves and fruits for the mating system analyses were collected from every flowering plant in the sampled areas during the fruiting season of 1993 (fruits from the flowering period of 1992). Seeds from individual plants were kept separated to calculate outcrossing rate for each plant. Because of problems with the germination of the seeds, not every sampled plant was included in the mating system analysis. The final sample size is shown in Table 1 and the sampled plants are marked in Fig. 1.

\section{Effect of number of flowers per plant on outcrossing rate}

Flower numbers for 34 of the sampled plants were counted every week over three consecutive weeks during the peak flowering period of 1992 . The flower number per plant is defined here as the mean over the counting period.

A correlation analysis was carried out to determine if outcrossing rate decreases as the number of flowers per plant increases. An analysis of covariance was performed to determine if the variation in outcrossing rates within each density area was influenced by the number of flowers per plant. The covariates in the different plant density groups were outcrossing rate of each plant and flower number per plant.

\section{Effect of plant density and number of flowers per plant on pollinator movements}

Data on pollinator movements among and within plants were collected within the sampled areas during the peak flowering period of 1992. Every morning one hummingbird was marked with a coloured ring and the following data were collected for the plants visited by these marked pollinators: (i) the number of flowers visited per plant; (ii) the number of times a pollinator visited one plant in $2 \mathrm{~h}$; (iii) the number of plants visited during $2 \mathrm{~h}$. Data for high- and low-density areas were collected on alternate days. The flower number of each visited tree was counted on the day the data on pollinator behaviour were collected. The behaviour of each observed 


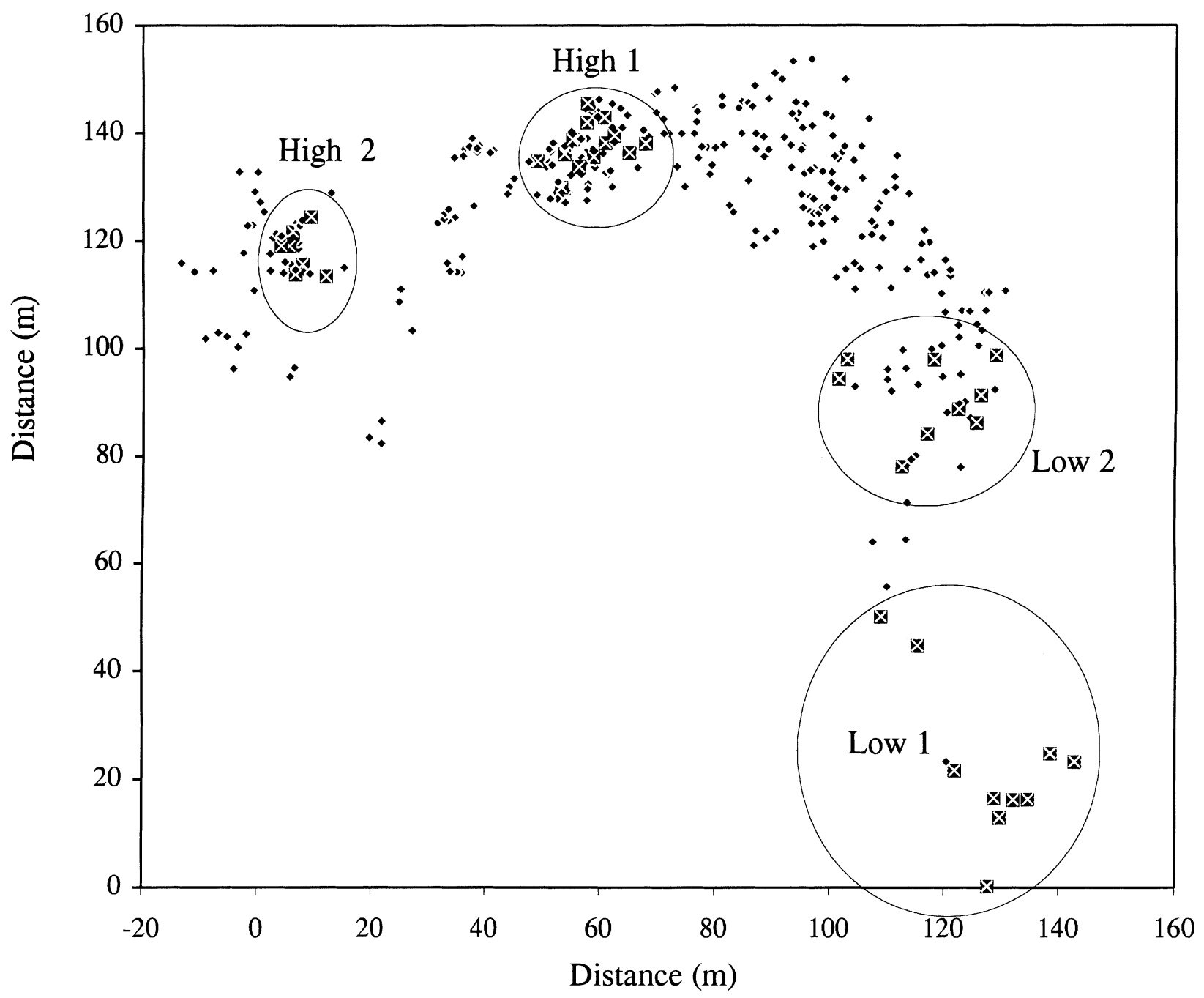

Fig. 1 Map of the population of Helicteres brevispira and the sampled plants.

pollinator was classified either as traplining or territorialist according to Feinsinger \& Colwell (1978).

\section{Electrophoresis}

Isozyme genetic markers were used for the mating system analyses. Sample sizes are in Table 1. Seeds were soaked in hot water at $70^{\circ} \mathrm{C}$ to break dormancy, and were germinated in the glasshouse. When the seedlings had three to four pairs of leaves, they were ground in liquid nitrogen and stained following the techniques of O'Malley et al. (1980). Electrophoretic procedures were as used by Franceschinelli \& Kesseli (1999).

Table 1 Multilocus and average single-locus outcrossing rates for Helicteres brevispira

\begin{tabular}{lccccrr}
\hline & & \multicolumn{4}{c}{ Outcrossing rate } \\
\cline { 3 - 5 } Sampled area & Density average (SD) & $N$ & Multilocus $t_{\mathrm{m}}(\mathrm{SD})$ & Single-locus $t_{\mathrm{s}}(\mathrm{SD})$ & $t_{\mathrm{m}}-t_{\mathrm{s}}(\mathrm{SD})$ & $F$ \\
\hline Low 1 & $2(1.3)$ & $10(311)$ & $0.478(0.039)$ & $0.445(0.038)$ & $0.033(0.017)$ & 0.049 \\
Low 2 & $8.6(2.2)$ & $9(280)$ & $0.490(0.045)$ & $0.484(0.048)$ & $0.006(0.017)$ & -0.233 \\
High 1 & $42(12)$ & $13(348)$ & $0.676(0.06)$ & $0.644(0.054)$ & $0.032(0.018)$ & 0.003 \\
High 2 & $32(1)$ & $9(300)$ & $0.646(0.05)$ & $0.635(0.053)$ & $0.011(0.014)$ & -0.268 \\
\hline
\end{tabular}

The density of each area is the average number of neighbouring plants within a $10 \mathrm{~m}$ radius of the sampled plants. $F$ is the average single-locus inbreeding coefficient of maternal parents. $N$ is the number of sampled plants, with number of seeds in parentheses. 
Loci banding patterns were consistent with typical subunit structures (Weeden \& Wendel, 1989). Polymorphic loci conformed to Mendelian expectations for segregation in the analysed progeny arrays. The mating system analysis used six polymorphic loci: uridine diphosphoglucomutase pyrophosphorylase (Ugpp), isocitrate dehydrogenase (Idh), glucose-6-phosphate isomerase $(G p i)$, triose-phosphate isomerase (Tpi), and 6-phosphogluconate dehydrogenase (6 pg).

\section{Data analysis}

Mating systems were analysed by examining the segregation patterns of allozymes in the open-pollinated progenies. Ritland's multilocus mixed-mating model (Ritland \& Jain, 1981; Ritland, 1990) was used to estimate the following parameters: (i) $t_{\mathrm{m}}$ and $t_{\mathrm{s}}$, the multilocus and average single-locus outcrossing rates (calculated by the Newton-Raphson method); (ii) $F$, the average single-locus inbreeding coefficient of maternal parents. These estimates were computed for the four density areas separately. Multilocus outcrossing rate $\left(t_{\mathrm{m}}\right)$ was also calculated for each family. Here, pollen allele frequencies were fixed at the population estimates. Variances of the above estimates were obtained using bootstrap methods (Ritland \& Jain, 1981), where the unit of resampling was the individual seedling. Bootstrapping was repeated 100 times. Deviations of the progeny genotype frequencies from model expectations were tested using the single-locus chi-squared goodness of fit of $t_{\mathrm{m}}$ to the data. As suggested by Ritland (1996), loci with highly significant chi-squared values were excluded from the multilocus estimates (see below). The MLT software (Ritland, 1990) was used for all these estimations.

\section{Results}

\section{Mating system and plant density}

In the mating system analyses for the different density areas, the chi-squared test was highly significant $(P<0.01)$ only for $6 p g-2$ in low density area 1 . All other loci fitted the model assumptions. The multilocus outcrossing rates for high-density areas 1 and 2 $\left(t_{\mathrm{m}}=0.676\right.$ and 0.646 , respectively) were higher and statistically different (chi-squared test, $P<0.001$ ) from those for low density areas 1 and $2\left(t_{\mathrm{m}}=0.478\right.$ and 0.490 , respectively) (Table 1). The single-locus outcrossing rate was lower than the multilocus for each density area, but not significantly different, except for the lowdensity area 1 (Table 1 ). Low density area 1 also had the highest fixation index $(F)$. The fixation index was very low in high-density area 1 , and negative in high-density area 2 and low density area 2 .

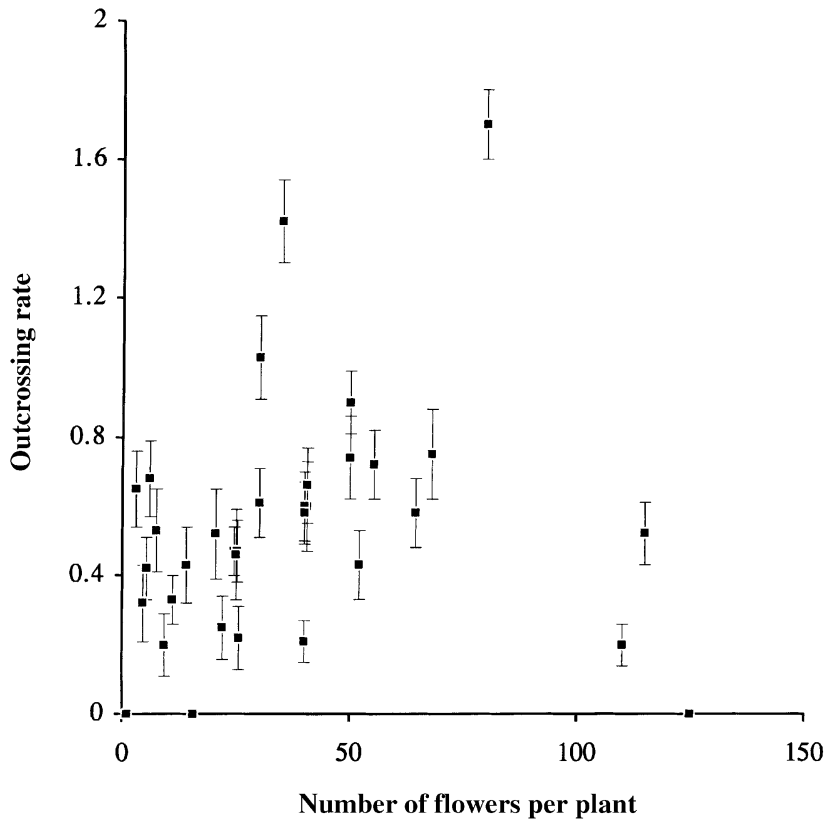

Fig. 2 Relationship between number of flowers per plant and outcrossing rate in Helicteres brevispira $(r=-0.03, N=35$, $P>0.8)$.

\section{Number of flowers per plant and outcrossing rate}

The analysis of covariance showed that number of flowers per plant did not influence the outcrossing rate in the sampled areas $(N=32, P<0.1)$ (Fig. 2).

\section{Pollinator movements vs. plant density}

In low density areas, most hummingbirds were acting as trapliners, visiting the same plants over long distances. Five trapliners (Chlorostilbon aureoventris females) were marked in low-density areas. Two other marked hummingbirds (C. aureoventris female and Amazilia lactea of unknown sex) were acting as generalists, because they rarely returned to the $H$. brevispira plants and were also visiting plants of other species. We could monitor 17 plants visited by trapliners and generalists in low density areas but we could not follow these trapliners to count the number of plants visited by them, because they flew over long distances among plants. Two birds (Amazilia lactea and Chlorostilbon aureoventris male) were defending three large trees with many flowers, showing territorial behaviour. Territorialists and trapliners visited similar numbers of flowers per plant in low-density areas, but territorialists visited the same plant more often than trapliners ( $t$-test, $P<0.01)$ (Table 2).

Territorialism was more common in high-density areas. Seven hummingbirds and 38 plants were monitored in high density areas and all seven hummingbirds 
Table 2 Data on pollinator behaviour for Helicteres brevispira. Mean values and standard deviations were calculated for the following types of data: (i) the number of flowers visited per plant; and (ii) the number of times a pollinator visits a plant in $2 \mathrm{~h}$. Sample size (number of plants) is in parentheses. See text for more details on data collection and results

\begin{tabular}{lcrc}
\hline & \multicolumn{2}{c}{ Low densities } & \\
\cline { 2 - 3 } $\begin{array}{l}\text { Type } \\
\text { of data }\end{array}$ & $\begin{array}{l}\text { Trapliner/ } \\
\text { generalist }\end{array}$ & \multicolumn{1}{c}{ Territorialist } & $\begin{array}{c}\text { High densities } \\
\text { Territorialist }\end{array}$ \\
\hline (i) & $12 \pm 4.4(17)$ & $10.4 \pm 3.5(6)$ & $3.3 \pm 0.6(38)$ \\
(ii) & $2.3 \pm 0.8(17)$ & $6 \pm 1.8(6)$ & $4.5 \pm 1.1(38)$ \\
\hline
\end{tabular}

defended feeding territories (three Chlorostilbon aureoventris male and four Amazilia lactea of unknown sex). At high density, the average number of plants in each territory was $12(\mathrm{SD}=2.0)$.

Hummingbirds visited significantly fewer flowers per plant in high than in low-density areas $(t$-test, $P<0.01$; Table 2). Therefore, the number of flowers visited per plant declined with increasing plant density (Fig. 3).

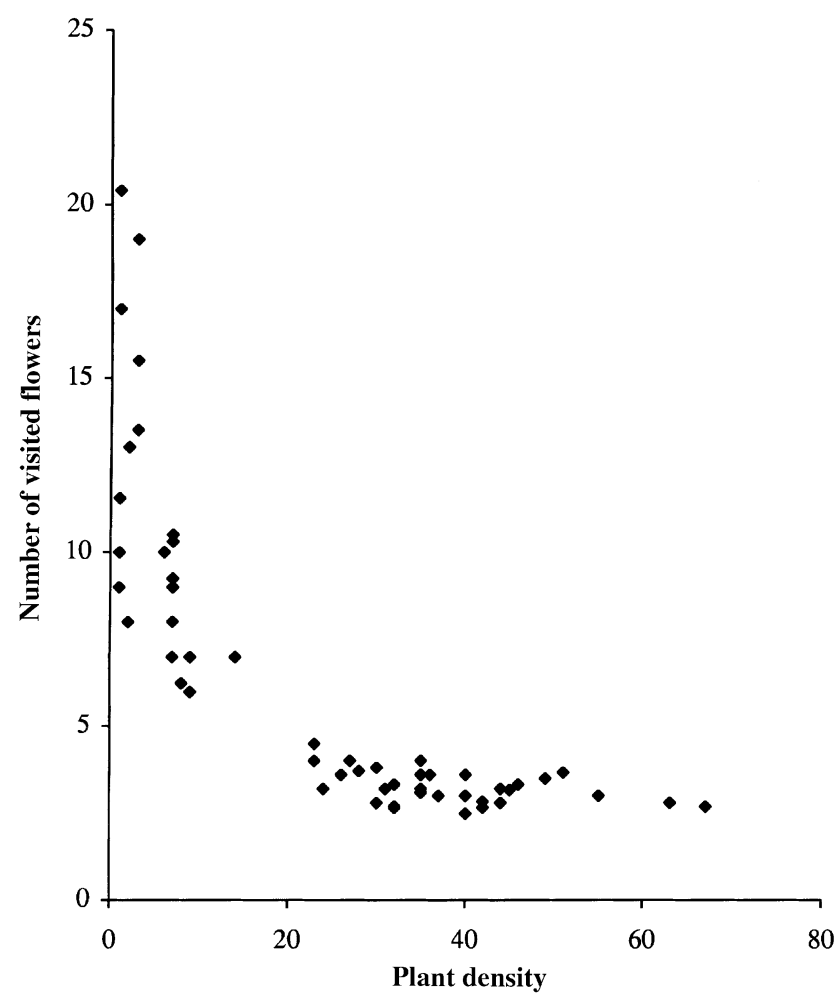

Fig. 3 Relationship between plant density and average number of visited flowers during each pollinator visit to a plant of Helicteres brevispira. Plant density is the number of neighbouring plants within a $10-\mathrm{m}$ radius of each sampled plant.

\section{Discussion}

The multilocus outcrossing rate ranged from 0.478 to 0.676 for $H$. brevispira. These values are lower than the average values (average $t_{\mathrm{m}}=0.815, \mathrm{SD}=0.038$ ) found for other tropical plant species (Murawski, 1995). Few species, such as Cavanillesia platanifolia $\left(t_{\mathrm{m}}=0.213-\right.$ $0.569)$, Ceiba pentandra $\left(t_{\mathrm{m}}=0.661\right)$ and Eucalyptus rhodantha $\left(t_{\mathrm{m}}=0.59-0.65\right)$, have a similar or lower $t_{\mathrm{m}}$ than $H$. brevispira. Selfing has been considered as a strategy to insure successful reproduction when exchange of pollen between plants is difficult, as in low plantdensity areas (Lefèvre, 1970; Allard, 1975). For colonizing species such as $H$. brevispira, selfing could be an important strategy for occupying open areas.

There was no significant difference between single- and multilocus estimates in the sampled areas of $H$. brevispira (Table 1). This indicates a lack of consanguineous mating. However, some authors have argued that the difference between these two estimates gives little indication of biparental inbreeding (Ritland, 1985; Coates \& Sokolowski, 1992). There are also indications that this population is substructured (Franceschinelli \& Kesseli, 1999). Substructuring could have induced biparental inbreeding and high fixation index $(F)$ in this population.

\section{Outcrossing rate vs. plant density}

Outcrossing rate was greater in high- than in low-density areas (Table 1). This result agrees with most of the studies that correlate outcrossing rate and plant density (Farris \& Mitton, 1984; Burdon et al., 1988; Wolff et al., 1988; Murawski et al., 1990; Murawski \& Hamrick, 1991, 1992a,b; van Treuren et al., 1993), and does not support the assumption that traplining pollinators always enhance pollen flow whereas territorialists reduce it.

Four factors may explain the positive association between plant density and outcrossing rate. The first and probably the most important is that plant density is inversely related to the number of flowers visited per plant (Fig. 3). At low plant densities, pollinators (trapliner or territorialist) visited higher numbers of flowers per plant, which increased the possibility of selfing in this self-compatible species. Secondly, in high-density areas, the territorial pollinators visited several plants within their territories and left their territories to visit other plants (1-8 plants) a few times a day. This allowed high pollen flow and outcrossing among plants in high density areas. Thirdly, territorialists in high-density areas returned to the same plant more often than did trapliners in low density areas (Table 2). This can increase outcrossing if pollen carry-over is not very large. Frequent visits to several plants in a short time is a common behaviour for a territorial pollinator when 
plant density is high, because it has to mark all the plants of its territory and defend them from intruders (Stiles \& Wolf, 1970; Pyke, 1981). On the other hand, it is expected that trapliners should visit as many flowers as they can on one plant in a low plant-density area, because they do not defend territory and have to travel long distances between plants (Pyke, 1981; Waddington, 1983). Fourthly, in high-density areas, plants are often smaller and very close to each other and have branches intermingled with other plants (Franceschinelli, pers. obs.). This factor facilitates the exchange of pollen among plants, as was suggested by Burdon et al. (1988) for Echium plantagineum.

\section{Outcrossing rate vs. number of flowers per plant}

The outcrossing rates and the numbers of flowers per plant were not correlated $(r=0.13, N=32, P>0.1)$. The increase in number of flowers per plant did not significantly change the outcrossing rate at the plant level. The effect of plant density on outcrossing rate in $H$. brevispira does not seem to interfere with the interaction between number of flowers and outcrossing rate, because the covariance analysis was not significant.

This lack of relationship between outcrossing rate and the number of flowers per plant may result from the variation in the foraging strategies of territorial and traplining hummingbirds arising from changes in plant densities. The territorialists visited few flowers of each plant in high-density patches, regardless of the number of flowers on the visited plant. Also, the few large plants in high-density areas often had their branches intermingled with the other plants, which, as mentioned before could facilitate cross-pollination. Thus, in high-density areas both large and small plants are likely to be more outcrossed than in low-density areas because of pollinator behaviour and proximity of plants.

In low-density areas, the territorialists, as well as the trapliners, visited several flowers per plant. Here, pollinator territories had only one or a few large plants. We observed two large plants in low-density areas, which were visited by territorial hummingbirds (not marked) late in the flowering season when other plants did not have many open flowers. Both plants had very low outcrossing rates that year $(0.24, \mathrm{SD}=0.09$, and zero). On the other hand, two other large plants in lowdensity areas visited by territorialists (marked) during the peak of the flowering season had higher outcrossing rates $(0.64, \mathrm{SD}=0.18$ and $0.41, \mathrm{SD}=0.21)$ than the first two. The pollinators of these last two plants visited three plants within their territories and a few others outside. The increased movement could have increased pollen flow among plants and consequently the outcrossing rates.

\section{Conclusions}

Overall, our results lead to four important conclusions. First, plant density is the most important determinant of outcrossing rate in $H$. brevispira. It regulates the outcrossing rate of a population, regardless of pollinator behaviour and the number of flowers per plant. Secondly, variation in pollinator foraging behaviour is a consequence of the interaction between plant density and number of flowers per plant. Thirdly, the number of flowers per plant by itself may not affect outcrossing rate but may interact with plant density and pollinator behaviour to influence the outcrossing rate of individual plants. Fourthly, the mating system in H. brevispira is dynamic, with a variable rate of outcrossing among individuals and subpopulations. Helicteres brevispira is a colonizing species and selfing must guarantee the production of fruits when plants are at low density, as at the edge of the gallery forests. In an open area, these plants may occur at high density and the exchange of pollen among plants may be high. Alternation of low and high outcrossing rate may occur during different periods in the metapopulation, and a mixed-mating system may be in equilibrium at the metapopulation level. As shown by Franceschinelli \& Kesseli (1999), population substructure also changes with variation in plant density. Thus, metapopulation dynamics may involve changes in the genetic characteristics of populations. Ecological and genetic changes may together determine the persistence and evolutionary fate of populations.

\section{Acknowledgements}

This work was supported by CNPq (Conselho Nacional de Desenvolvimento Científico e Tecnológico) to the first author and grants from the National Science Foundation to K. Bawa. Thanks to Eliane Oliveira for all her help in the field. We are also indebted to Michael Chase, Lelia Orrell and Flávio a. M. Santos for their assistance and advice. We are grateful to Dr Kermit Ritland for his comments on the final version of this paper. Finally, we thank Dr Terry Crawford and two anonymous reviewers for helpful comments on the manuscript.

\section{References}

ALlaRD, R. W. 1975. The mating system and microevolution. Genetics, 79, 115-126. 
AUSGSPURGER, C. K. 1980. Mass-flowering of a tropical shrub (Hybanthus prunifolius): influence on pollination attraction and movement. Evolution, 34, 475-488.

BAKER, H. G. 1973. Evolutionary relationships between flowering plants and animals in American and African tropical forests. In: Meggers, B. J., Ayensu, E. S. and Duckworth, W. D. (eds) Tropical Forest Ecosystems in Africa and South America: A Comparative Approach, pp. 145-159. Smithsonian Institution Press, Washington, DC.

BARRET, S. C. H., HARDER, L. D. AND COLE, W. W. 1994. Effects of flower number and position on self-fertilization in experimental populations of Eichornia paniculata. Funct. Ecol., 8, 526-535.

BOShIER, D. H., CHASE, M. R. AND BAWA, K. S. 1995. Population genetics of Cordia alliodora (Boraginaceae), a neotropical tree. 3. Gene flow, neighborhood, and population structure. Am. J. Bot., 82, 484-490.

BURDON, J. J., JAROSZ, A. M. AND BROWN, A. H. D. 1988. Temporal patterns of reproduction and outcrossing in weedy populations of Echium plantagineum. Biol. J. Linn. Soc., 34, 81-92.

COATES, D. J. AND SOKOLOWSKI, R. E. S. 1992. The mating system and patterns of genetic variation in Banksia cuneata A.S. George (Proteaceae). Heredity, 69, 11-20.

CRAWFORD, T. J. 1984. What is a population? In: Shorrocks, B. (ed.) Evolutionary Ecology, pp. 135-173. Blackwell Scientific Publications, Oxford.

FARris, M. A. AND MitTon, J. B. 1984. Population density, outcrossing rate, and heterozygote superiority in ponderosa pine. Evolution, 38,1151-1154.

FEINSINGER, P. 1978. Ecological interactions between plants and hummingbirds in a successional tropical community. Ecol. Monogr., 48, 269-287.

FEINSINGER, P. AND COLWELl, R. K. 1978. Community organization among neotropical nectar-feeding birds. Am. Zool., 18, 779-795.

FRANCESCHINELLI, E. V. 1989. Biologia Da Reprodução de Espécies de Helicteres: $\mathrm{H}$. brevispira, $\mathrm{H}$. ovata $e$ H. sacarolha. MSc Thesis, Universidade Estadual de Campinas, Campinas-SP, Brazil.

FRANCESCHINELli, E. V. AND KeSSELI, R. 1999. Population structure and gene flow of the Brazilian shrub Helicteres brevispira. Heredity, 82, 355-363.

GERBER, M. A. 1985. The relationship of plant size to selfpollination in Mertensia ciliata. Ecology, 66, 762-772.

KARRON, J. D., THUMSER, N. N., TUCKER, R. AND HESSENAUER, A. J. 1995. The influence of population density on outcrossing rates in Mimulus ringens. Heredity, 75, 175-180.

LEFÈVRE, C. 1970. Self-fertility in maritime and zinc mine populations of Armeria maritima (Mill.) Willd. Evolution, 24, 571-577.

LEVIN, D. A. 1986. Breeding structure and genetic variation. In: Crawley, M. J. (ed.) Plant Ecology, pp. 217-252. Blackwell Scientific Publications, Oxford.

LINHART, Y. B. 1973. Ecological and behavioral determinants of pollen dispersal in hummingbird-pollinated Heliconia. Am. Nat., 107, 511-523.
MURAWSKI, D. A. 1987. Floral resource variation, pollinator response, and potential pollen flow in Psiguria warcewiczii. Ecology, 68, 1273-1282.

MURAWSKI, D. A. 1995. Reproductive biology and genetics of tropical trees from a canopy perspective. In: Loman, M. and Nadkarni, N. (eds) Forest Canopy, pp. 457-493. Academic Press, New York.

MURAWSKI, D. A. AND HAMrick, J. L. 1991. The effects of the density of flowering individuals on the mating systems of nine tropical tree species. Heredity, 67, 167-174.

MURAWSKI, D. A. AND HAMRICK, J. L. 1992a. The mating system of Cavanillesia platanifolia under extremes of flowering-tree density. Biotropica, 24, 99-101.

MURAWSKI, D. A. AND HAMRICK, J. L. 1992b. Mating system and phenology of Ceiba pentandra (Bombacaceae) in Central Panama. J. Hered., 83, 401-404.

MURAWSKI, D. A., HAMRICK, J. L., HUBBEL, S. P. AND FOSTER, R. B. 1990. Mating systems of two bombacaceous trees of a Neotropical moist forest. Oecologia, 82, 501-506.

MURAWSKI, D. A., GUNATILLEKE, I. A. U. N. AND BAWA, K. S. 1994. The effects of selective logging on inbreeding in Shorea megistophylla (Dipterocarpaceae) from Sri Lanka. Conserv. Biol., 8, 997-1002.

O'MALLEY, D. M., WHEELER, N. C. AND GURIES, R. P. 1980. A Manual for Starch Gel Electrophoresis. University of Wisconsin Press, Madison, WI.

PARRA, V., VARGAS, C. F. AND EGUIARTE, L.E. 1993. Reproductive biology, pollen and seed dispersal, and neighborhood size in the hummingbird pollinated Echeveria gibbiflora (Crassulaceae). Am. J. Bot., 80, 153-159.

PYKE, G. H. 1981. Optimal foraging in hummingbirds: rule of movement between inflorescences. Anim. Behav., 27, 889-896.

RITLAND, K. 1985. The genetic mating structure of subdivided populations I. Open-mating model. Theor. Pop. Biol., 27, 51-74.

RITLAND, K. 1990. A series of FORTRAN computer programs for estimating plant mating systems. J. Hered., 81, 235-237.

RITLAND, K. 1996. Multilocus mating system program manual MLTR, version 1.1. Program available via ftp at 128.100.165. 100.

RITLAND, K. AND JAIN, S. K. 1981. A model for the estimation of outcrossing rate and gene frequencies using $n$ independent loci. Heredity, 47, 35-52.

SCHмiтt, J. 1983. Density-dependent pollinator foraging, flowering phenology, and temporal pollen dispersal patterns in Linanthus bicolor. Evolution, 37, 1247-1257.

STACY, E. A., HAMrick, J. L. AND CONDIT, R. 1996. Pollen dispersal in low-density populations of three neotropical tree species. Am. Nat., 148, 275-292.

STILES, F. G. AND WOLF, L. L. 1970. Hummingbird territoriality at a tropical flowering tree. Auk, 87, 467-491.

VAN TREUREN, R., BIJLSMA, R., OUBORG, N. J. AND VAN DELDEN, w. 1993. The effects of population size and plant density on outcrossing rates in locally endangered Salvia pratensis. Evolution, 47, 1094-1104. 
WADDINGTON, K. D. 1983. Foraging behavior of pollinators. In: Real, L. (ed.) Pollination Biology, pp. 213-239. Academic Press, Orlando, FL.

WEEDEN, N. F. AND WENDEL, J. F. 1989. Genetics of plant isozymes. In: Soltis, D. E. and Soltis, P. S. (eds) Isozymes in Plant Biology, pp. 46-72. Dioscorides Press, Portland, OR. WOLFF, K., FRISCO, B. AND VAN DAMME, J. M. M. 1988. Outcrossing rates and male sterility in natural populations of Plantago coronopus. Theor. Appl. Genet., 76, 190-196.
WRIGHT, S. 1946. Isolation by distance under diverse systems of mating. Genetics, 31, 39-59.

WYATT, R. 1980. The reproductive biology of Asclepias tuberosa: I. Flower number, arrangement, and fruit-set. New Phytol., 85, 119-131. 